\title{
Final offer arbitration and the State Sector Act
}

\author{
Alan Geare*
}

The first version of the State Sector Bill (State Sector Bill (1)) specified that the Labour Relations Act 1987 would apply in the State Services with respect to dispute settlement. Under the Labour Relations Act 1987, the procedure of conciliation may be used only in situations involving two or more employers (s.134(4)). Hence, to be consistent, conciliation was not available as an option in the state services. Furthermore, arbitration under the Labour Relations Act only operates when both parties agree to its use, and thus compulsory arbitration is no longer available. Thus, the State Sector Bill (1) presented the state unions with the scenario of losing their right to annual general adjustments and with the possibility of arbitration no longer being available (should the State Services Commission (SSC) or the corresponding "employer" refuse to agree to arbitration). In addition to these very real problems, there were also fears among some groups that they would/could lose other rights (such as parental leave) not written into determinations or otherwise provided for in legislation. Some state unions deplored the fact that State Sector Bill (1) encouraged strike action - and went out on strike in protest. After protests and strike action, and further submissions, a second version of the State Sector Bill appeared dated 16 March 1988. This, State Sector Bill (2), provides the basis for the following discussions. It is assumed the State Sector Act, due to take effect from April 1, will not be significantly altered from this.

State Sector Bill (2) provides a number of changes with respect to dispute settlement. Under Schedule 1B, provision is made allowing disputes to be settled by conciliation and arbitration. Hence, the state unions may now negotiate awards as well as agreements. Of course, arbitration, as in the private sector, would be provided by the Arbitration Commission, but only if both the union and the SSC agree. The Labour Government, however, has made a further "concession", in that they now do allow for compulsory arbitration. Under s.48(4) of State Sector Bill (2), if a union requests by 30 June 1988 for a compulsory arbitration clause, the SSC shall agree to the request and the clause will be included in the award or agreement. The concession is not overly generous as it has two fishhooks embedded in it. The first is that the union must agree to waive its rights to engage in lawful strikes over disputes of interest or new matters granted under s.233 (1a1c) of the Labour Relations Act 1987. Given that the state unions have been claiming that they never want to strike, this provision may not be deemed to be serious. The second fishhook is that the type of arbitration provided is known as final offer arbitration. 


\section{Background to final offer arbitration}

Final offer arbitration (FOA) first received general attention in academic circles after an influential paper by Stevens (1966). Among the flurry of papers generated by Stevens' work, one claimed that FOA was first used by a Toronto hydro engineer Val Scott in 1964. However the claim that FOA is of recent origin has been disputed by Treble (1986) who pointed out that FOA was used intermittently by conciliation boards in several British industries from 1860 on. Treble states that the concept originated in the Nottingham hosiery industry in 1860 , but although FOA was available it was never actually used and it was later introduced, and used, in the coalmining industry. Treble (1986) noted:

The most striking facts about the experience of the boards are that final offer arbitration did not last long in most coalfields and that opposition to it came, not from the negotiators, but from the arbitrators. (p.92).

Collective bargaining, conciliation, arbitration (conventional style) and FOA are all dispute settling processes. They can be employed to settle interest disputes (over the establishment of agreements), rights disputes (over the interpretation or application of agreements) or personal grievances. The focus of this paper is primarily on interest disputes.

It is generally conceded that for collective bargaining not to be a sham, unions must have the right to strike or otherwise they will always operate from a position of weakness. Hence, if the freedom to strike is curtailed or withdrawn, access to arbitration is provided as compensation. Thus in New Zealand's private sector, since strikes over rights disputes are illegal, arbitration from the Labour Court is provided. Under the Labour Relations Act 1987, strikes over interest disputes are now legal (with provisos), so arbitration is not a guaranteed option, although available if both parties agree.

The objective of conventional arbitration is to provide an acceptable and workable solution. The role of the arbitrator is to consider the cases put by both sides and then to use "arbitral discretion" to reach a decision and make an award. It is clearly possible that the arbitrator may decide totally in favour of one party, but usually there is a compromise between the two positions, not only to make the settlement more acceptable to both sides but also to satisfy the arbitrator's concept of justice.

FOA is a variant of conventional arbitration which requires the arbitrator to choose one or other of the two parties' final offers. The arbitrator is not allowed to compromise, and cannot be concerned with acceptability and workability, but instead must accept the union's or employer's final offer. Hence, taken simply as a method of arbitration (as opposed to a method of dispute settlement), FOA is clearly inferior to conventional arbitration. The latter can operate as FOA when the situation warrants, or can make compromises when that appears more suitable. As already quoted, Treble (1986) pointed out that in the nineteenth century, opposition to the use of FOA came from the arbitrators. Weitzman and Stochaj (1980, p.33) analyse the views of eighteen arbitrators involved in both conventional arbitration and FOA and discovered that "two-thirds of the interviewees stated that they would prefer conventional arbitration over final-offer arbitration, because the former gives the neutral more discretion and the ability to compromise differences."

However FOA was not designed as a method of arbitration so much as a method of dispute settlement, with objectives differing from conventional arbitration. Unlike conventional arbitration, the objective of FOA is not to achieve an acceptable and workable solution. 
Instead the objective of its original proponents was to make the cost of failing to reach a negotiated settlement so high that both parties would be forced - by fear - to negotiate and reach a settlement. Scott, the hydro-engineer mentioned earlier, is of the view that "arbitration of any kind is only an alternative to strikes and lockouts and not a substitute for negotiations. Hence there is no reason to make arbitration just or pleasant" (Perigoe, 1973, p. 31). Thus, Scott developed FOA which he never intended to be a means of producing a just or pleasant solution but rather, to use the colourful language of its proponents, he intended it to be "the hydrogen bomb poised above the bargaining table whose very terror should ensure its non-use" (Holden,1976, p. 28). The "non-use" is brought about (in theory) by the fact that the losing party will have gained nothing from the arbitration process and will have to accept the other party's final offer (or demand). It is this high cost of being forced to accept what could be a demand so great that it is economically crippling, or an offer so low that it would mean loss of office for the union negotiators that is intended to deter the parties from resorting to FOA and force them to negotiate a settlement.

In general, interest disputes are not over a single issue but over a number of issues. Hence there are a number of obvious variations of FOA. Under the basic variant, the arbitrator selects what he or she believes to be the more reasonable of the union's or management's final package. These could involve, for example, staffing levels, working conditions, the payment system, the level of the basic pay rate and holidays. The arbitrator has to judge on an overall basis which package is the most reasonable. This clearly could result in some issues being decided in favour of a party which, on those particular issues, was less reasonable. An alternative variant is that the arbitrator should consider each issue in turn and select the most reasonable final offer for each issue separately. There is thus compromise over the package as a whole but not for any single issue. One observer claims that the case for FOA :

is clearer in the single issue dispute than in the multiple issue dispute. In the latter, which is the usual case, difficulties of calculating the rate of exchange and trade-off among the various disputes increase the likelihood that the Board's decision will not be an optimal one (Rogow,1973, p.28).

This observation overlooks the fundamental purpose of FOA which is to increase the potential costs of failing to negotiate a settlement, not to produce an optimal decision. Thus if one accepts the rationale behind FOA, one is logically compelled to prefer total package arbitration to issue by issue arbitration, since there is more uncertainty and the potential costs of not settling are even greater.

The FOA offered under the State Sector Bill (2) ( and in the final act - Editor ) is "in total", with s. 8 of Schedule 1 B stipulating that the Arbitration Commission "must accept in full the final offer made by one of the parties" and further that it "may not adopt only a part or parts of one final offer and a part or parts of the other final offer".

\section{Evaluation of final offer arbitration}

This paper will give an evaluation of FOA, considering in turn: a) the theoretical justification for FOA according to its proponents; b) how FOA works according to laboratory simulations; c) how FOA should work according to mathematical models and d) how FOA appears to work in practice. There will be a concluding discussion with regard to FOA and the State Sector Act. 
The author has previously expressed the view that "the basic logic underpinning the concept of FOA is weak" (Geare,1978, p.385) and nothing that has occurred in the intervening decade has altered that opinion. The theoretical justification for FOA seems to rest on three inter-dependent premises:

Premise 1 : That conventional arbitration is inferior to collective bargaining as a method of dispute settlement.

Premise 2 : That dispute settlement processes should encourage collective bargaining.

Premise 3 : That conventional arbitration has a "narcotic effect" (Feuille,1975, p.304) on the parties causing them to become "arbitration addicts" while FOA discourages its use and encourages collective bargaining.

Premise 1 seems to be regarded by some writers as a universal truth which needs no defence or justification. Thus, Northrup states that "free collective bargaining is the best solution we have been able to devise to the employer-employee relations" (1966,pp.1823 ). However, this assertion is in fact unproven. This does not mean that the premise is in fact false, but does support the view expressed by Hancock a quarter of a century ago that there were "no reasons which are neither trivial nor double-edged advanced by ... (supporters of either side) ... which warrant any firm preference for arbitration or collective bargaining". (Hancock,1962, p.20)

In the earlier paper already quoted, this writer has asserted that the perceived superiority of collective bargaining over arbitration is based on a number of myths - that bargaining necessarily involves a "meeting of minds", that the process of bargaining is necessarily to narrow differences while that of arbitration is to broaden differences, that bargaining produces more commitment and finally that arbitration involves a multitude of lawyers. That earlier paper argued that these myths do not have universal validity and indeed that the evidence from the New Zealand private sector shows that in the New Zealand context the myths are indeed false.

As Farber (1981) points out "the major criticism of conventional interest arbitration is that the arbitrator tends to "split the difference" between the final positions of the parties" (p.70). This criticism, however is logically absurd. If arbitration did simply involve "splitting the difference" then clearly the respondent in any dispute situation would place their counter-offer such that the middle point between the offers coincided with the respondent's actual preferred position. They would then move only in response to an equal move by the applicant. For example:

a) A union demands a 28 percent wage increase whilst employers wish to give 6 percent. Employers therefore counter-offer a 22 percent decrease and will move only in response to a union decrease. Split-the-difference arbitration would always result in a 6 percent
increase.

b) Employers demand a reduction in staffing from 320 to 250 . The union wants the status quo preserved, so it counter-demands an increase in staffing to 390 and will reduce this only in response to an increase from the employers. Split-the -difference arbitration would always result in the status quo. These situations are clearly unrealistic, because arbitration is never so simplistic and
predictable. 
Notwithstanding the palpable stupidity of the argument, many do adhere to the "split the difference" belief. This is probably because some arbitration outcomes appear to split the difference. When this occurs, however, it is likely, as Farber (1981) suggests, to arise from the fact that:

the parties will actually take final positions that are located symmetrically around the arbitrator's notion of the equitable outcome. Thus, it is the expected arbitration outcome which determines the bargaining positions rather than the reverse (p.71).

Collective bargaining and arbitration (and indeed FOA) are simply processes in the industrial relations system. At any time, the vast majority of any one, two or three of the major parties (government as legislator, employers, unions and work groups) may prefer one particular process. Clearly, if all three prefer one process then it will be selected for the time being. In all probability, the parties will have disagreements within themselves and between each other. The only logical conclusion about the superiority of processes is to argue from the point of view of a particular party at a particular time. Rather obviously, weaker parties tend to favour arbitration while parties in strong positions favour collective bargaining. At different times, employers in the New Zealand private sector have supported and at other times opposed arbitration. The unions have behaved in identical fashion.

Premise 2 is clearly both simply a value judgement and is also totally dependent for its basic logic on premise 1 being accepted. If in fact collective bargaining is not necessarily superior to arbitration, there seems no logical reason why the chosen process should encourage bargaining.

The third premise is apparently the creation of the then United States Secretary of Labor, W. Willard Wirtz, who in 1964 claimed that "a statutory requirement that labor disputes be submitted to arbitration has a narcotic effect on private bargainers ... they will turn to it as an easy and habit forming release from the ... obligation of hard responsible bargaining" (Wheeler,1977, p.117). This metaphor appealed to American writers (such as Feuille) who incorporated it into their writings referring to arbitration addicts. Since the first premise is unproven, then whether or not arbitration produces "arbitration addicts" could be a non-issue. Indeed, if arbitration is actually a superior process to bargaining, the addiction would be a blessing not a bane. However, again as argued earlier by this writer, New Zealand experience in the private sector has shown that the availability of arbitration does not necessarily result in the parties always resorting to it. Certainly the negotiations which precede possible arbitration will clearly be influenced by the likely arbitration award, but the strictly limited use made over the years of the Court of Arbitration and Arbitration Court shows that the premise is not true in New Zealand's experience.

It has already been pointed out that as FOA provides a more limited scope for arbitration than conventional arbitration, it is clearly inferior if judged as a type of arbitration. In any dispute, if the "best" (however determined) award is one or other final offer, then that can be achieved by conventional arbitration as well as FOA. However, if the "best" award is a compromise, FOA cannot achieve it. For FOA to be other than an unpleasant joke, it must achieve what its proponents claim - both parties being scared into negotiation which results in either a settlement or little difference in the final positions.

There are difficulties with accepting evidence both from actual experience and from laboratory simulations and mathematical modelling. Notz and Starke (1978) point out that field evidence gives contradictory results: 
partially due to the studies being either cross-sectional or case, and the results raise many questions about their internal validity so that there are many alternative and plausible explanations for the relationships observed (p.190).

They go on to point out that "those issues of internal validity can be dealt with in the laboratory". However laboratory simulations and mathematical models raise serious questions as to the extent to which these results can be extended to apply to actual industrial relations situations. As Bazerman and Farber (1982, p.88) observe "conclusions drawn from data based on simulations are not always generalizable to actual cases." Given these caveats this paper will now examine such evidence as exists upon which to evaluate FOA.

\section{Laboratory simulations}

There have been a number of laboratory simulations where subjects, usually students but sometimes practising arbitrators, role play dispute situations. In general, they were expected to negotiate a settlement with the possibility of conventional arbitration or FOA if a settlement could not be reached. Some studies tried to compare conventional arbitration with FOA, while others were examining the process of FOA.

Comparative studies produced conflicting results. Two studies (Notz and Starke,1978, Starke and Notz,1981) produced results supportive of FOA and concluded that FOA does result in converging offers. However Johnson and Tullar (1972) found that in situations where there was a high need for face-saving, FOA was appreciably worse than conventional arbitration at producing convergence.

Studies on the process of using FOA produced results which should interest policymakers. In separate studies, Bazerman and Neale (1982), and de Nisi and Dworkin (1981) found that training in FOA and a thorough understanding of the implications of FOA were required before there was any change in behaviour of the subjects. Hence if policy-makers want FOA to change behaviour - then these studies suggest prior education is essential.

A study (Farber and Bazerman, 1986) using actual arbitrators (there are sufficient numbers in the United States to be able to experiment with them), discovered that the decision process by which arbitrators make conventional awards or FOA awards is the same. With knowledge of the arbitrators' ideal conventional award, the researchers could accurately predict the FOA award in just under 90 percent of the cases. This fact however is disturbing. It means that in 10 percent of cases, the arbitrators made illogical awards (based on their own values). This is indeed a prime argument against FOA. If the parties do not converge, then one or other extreme offer has to be chosen. Evidence suggests that in such a case the "least ridiculous" offer may not always be picked.

\section{Mathematical models}

During the 1980 s a number of studies appeared which assessed FOA according to mathematical models, usually employing utility theory and game theory. Those tested whether convergence of offers can be predicted and whether Nash optimal solutions (Nash 1950 and 1953) arise. These studies have little face validity to non-mathematicians, and one suspects that the general attitude to such studies is to accept them if they support one's preconceived ideas and dismiss them as obvious rubbish if they do not. Practitioners who are non- mathematicians will be interested to read such confident and definite 
statements as : "each party calculates the expected utility to them of using the arbitration procedure:

$$
\mathrm{E}\left(\mathrm{U}_{\mathrm{a}}\right)={ }_{\infty} \int \infty 1-\mathrm{e}^{\mathrm{YaCa}} \mathrm{f}\left(\mathrm{Y}_{\mathrm{a}} ; \mathrm{Y}_{\mathrm{aF}}, \mathrm{O}_{\mathrm{a}}^{2}\right) \mathrm{dy}_{\mathrm{a}}
$$

(Farber and Katz,1979,p.57).

This writer would be much happier to read "the behaviour of the parties can be explained to some extent by the following expected utilities ..."

As with laboratory studies, the results from the mathematical modelling are not definite, but tend to be unsupportive of FOA. Brams and Merrill (1983) consider their model demonstrates that in a situation of uncertainty (as to the arbitrator's considered optimum solution) FOA produces divergence not convergence. Farber (1980) considers that negotiated settlements reached under FOA will be skewed against the more risk-averse party. If his findings are correct, then state unions should consider whether they or the Government are more risk averse. In the view of this author, the probability is that, for example, teachers unions are more risk-averse than the Government. Treble (1985) has a model which suggests that "FOA is not likely to be more successful than CA (Conventional Arbitration) in producing agreements although the observed spread of final offers is likely to be less in FOA than in CA" (p.181).

\section{Field evidence}

If FOA is ever employed, then it has failed according to its original proponents. As already mentioned, they assumed the risk of losing everything would be such that parties would never employ FOA. Thus, to a certain extent one could claim that if FOA is actually used it has failed. However, FOA should also be judged as a method of dispute settlement. If everybody enjoys a gamble, and are prepared to live with the consequences, then possibly one should support FOA even if it appears theoretically unsound.

FOA has predominantly been used in the public sector in the U.S., and also in setting salaries for professional baseball players. In most situations strikes are illegal (and the bans are effective) so the "acceptability" of the FOA decisions are hard to evaluate. Certainly some writers are enthusiastic about FOA, while others are not.

The results of FOA are difficult to evaluate. Ashenfelter and Bloom (1983) warn that "it takes careful analysis before box scores or win-loss records are of any value in determining the integrity or fairness of an arbitration system" (p.539). In their two papers, they analyse results in New Jersey, a state where a "remarkable statute provides for conventional arbitration of pay disputes if the two parties can agree to this, but requires the use of final-offer arbitration if they cannot $(1984$, p.111). They point out that while unions win at FOA two-thirds of the time, the increases they get from FOA are lower than under conventional arbitration. They win at FOA because they are less ambitious than the employers, but they in fact do better under conventional arbitration (1983, pp.538-9).

Chelius and Dworkin (1980, p.305) consider that FOA operates well and "appears to encourage bilateral collective bargaining and redistribute power in much the same manner as would the right to strike." On the other hand Robitzek (1979) considers FOA operates as an alternative to collective bargaining. Buxton, Chief of the Employee and Labor Relations Division at Air Force Command HQ, wrote that agreeing to FOA was "rash and 
somewhat akin to playing Russian roulette" (1986, p.171). Perlman (1979), a proponent of FOA, enthuses over its success in encouraging negotiated settlements in Michigan and Oregon but concedes that the reverse occurred in Wisconsin and Massachusetts.

\section{Conclusions from the evidence}

It appears to this writer impossible to conclude from the evidence as to what will occur in any particular situation if FOA is employed. It is possible that it will encourage more settlements than would occur if conventional arbitration were available. This, however, is not assured. If the two offers are reasonably close then the parties may in fact prefer FOA awards, but again this is not assured. What all parties must be aware of is that there is a possibility under FOA that an extreme award has to be made with very major consequences indeed.

The Labour Government has made it clear that it wants unions to negotiate settlements rather than use arbitration. It has given unions the right to strike (within 60 days of the expiry of the award or agreement) and hence feels under no obligation to provide arbitration. This latest move to offer FOA can be considered part of an overall strategy, rather than evidence that the Government sees particular merit in FOA.

The unions have only three months to ensure they get a compulsory arbitration clause, as the legislation requires that the unions decide whether to request the clause by 30 June 1988. After that the State Services Commission is not obliged to agree to it. By putting in the time constraint, the Government is suggesting that FOA is an advantage to the unions. They will clearly be diverted from their straight out opposition to the State Sector Act. Furthermore, if the unions reject the offer on the basis that they have to agree to a two-year no strike agreement, they are made to look shallow and insincere in their claims that they object to the State Sector Act because it obliges them to go on strike. If unions object to FOA because it has theoretical weaknesses, they will be told that if they are reasonable, they have nothing to fear. The problem of course is that in some disputes both sides take widely differing views and both sides feel they are right and reasonable.

To conclude, this writer does not consider that FOA will necessarily cause chaos, but does believe the possibility exists of an extreme award having to be made. THe resulting problems could be severe. At this stage, it is also possible that no union will opt for FOA and it becomes a total non- event or that unions or the Government happily accept FOA awards.

\section{References}

Ashenfelter O and Bloom D (1983) The pitfalls in judging arbitrator impartiality by winloss tallies under final offer arbitration Labour law journal August: 534-539.

Ashenfelter O and Bloom D (1984) Models of arbitrator behaviour: theory and evidence American eonomic review $\mathbf{7 4 : 1 1 1 - 1 2 4 .}$

Bazerman M H and Farber H S (1985) Arbitrator decision-mak $\mathrm{ng}$ : when are final offers important? Industrial and labour relations review 39 (1):76-89.

Bazerman M H and Neale M A (1982) Improving negotiation effectiveness under final offer arbitration: the role of selection and training Journal of applied psychology 67
(5):543-548. 
Brams S J and Merrill S (1983) Equilibrium strategies for final-offer arbitration: there is no median convergence Management science 29 (8):927-941.

Buxton V (1986) Pitfalls and pratfalls of impasse resolution procedures in the Federal Government: a negotiator's experience Labour l aw journal March:167-179.

Chelius J R and Dworkin J B (1980) An economic analysis of final offer arbitration as a conflict resolution device Journal of conflict resolution 24 (2):293-310.

de Nisi A S and Dworkin J B (1981) Final offer arbitration and the naive negotiator Industrial and labour relations review 35 (1):78-87.

Farber H S (1980) An analysis of final offer arbitration Journal of conflict resolution 24 (4):683-705

Farber H S (1981) Splitting the difference in interest arbitration Industrial and labour relations review 35 (1):70-77.

Farber H S and Bazerman M H (1986) The general basis of arbitrator behaviour: an empirical analysis of conventional and final offer arbitration Econometrica 54 (6):15031528.

Farber H S and Katz H C (1979) Interest arbitration outcomes and the incentive to bargain Industrial and labour relations review 35 (1):55-63.

Feuille P (1975) Final offer arbitration and the chilling effect Industrial relations 14 (3):302-310.

Geare A J (1978) Final offer arbitration: a critical examination of the theory Journal of industrial relations $20(4): 373-385$.

Hancock K J (1962) Compulsory arbitration versus collective bargaining: three recent assessments Journal of industrial relations 4 (1): 20-31.

Holden L T (1976) Final offer arbitration in Massachusetts: one year later Arbitration journal 31 (1):26-35.

Johnson D F and Tullar W L (1972) Style of third party intervention, face-saving and bargaining behaviour Journal of experimental social psychology 8: 319-330.

Nash J (1950) The bargaining problem Econometrica $18: 155-162$.

Nash J (1953) Two-person cooperative games Econometrica $21: 128-140$.

Northrup H R (1966) Compulsory arbitration and government intervention in labour disputes Washington LPA.

Notz W W and Starke F A (1978) Final-offer versus conventional arbitration as means of conflict management Administrative science quarterly $23: 189-203$.

Perigoe J R (1973) Does final offer selection offer a strike alternative? Canadian personnel and industrial relations journal 20 (1): 30-31. 
Perlman P I (1979) Final offer arbitration: a pre-trial settlement device Harvard journal on legislation $16: 513-542$.

Robitzek W D (1979) Final offer arbitration and the labour-management posse: heading off municipal disputes at the impasse Boston University law review 59 (1):105-128.

Rogow R (1973) Final offer selection: some limitations Canadian personnel and industrial relations journal $20(1): 28$

Starke F A and Notz W W (1981) Pre-and post-intervention effects of conventional versus final offer arbitration Academy of management journal 24 (4) : 832-850.

Stevens C M (1966) Is compulsory arbitration compatible with bargaining? Industrial relations $\mathbf{5}(2): 38-52$.

Treble J G (1985) Conventional arbitration final offer arbitration and the chilling effect Economics letters $17: 177-181$

Treble J G (1986) How new is final offer arbitration? Industrial relations 25 (1) : 92 94.

Weitzman J and Stochaj J M (1980) Attitudes of arbitrators toward final-offer arbitration in New Jersey Arbitration journal $35: 25-34$.

Wheeler H N (1977) Closed-offer: alternative to final-offer selection Industrial relations 16 (3) :298-305. 